\title{
Prediksi Ignition Delay Mesin Diesel Berbahan Bakar Ganda
}

\author{
Arifin Siagian dan Mawardi Silaban \\ Balai Besar Teknologi Energi (B2TE), BPPT \\ Kawasan PUSPIPTEK, Cisauk, Tangerang Selatan, Banten, 15314 \\ Email: arifinsiagian64@yahoo.com; silaban90210@yahoo.com
}

\begin{abstract}
ABSTRAK
Pada mesin diesel ada tenggang waktu antara sejak dimulainya penginjeksian solar (periode injeksi) ke dalam silinder bakar mesin, kemudian terbentuk campuran udara+embun solar sampai terjadi titik api yang mula-mula atau periode pengapian. Tenggang waktu atau keterlambatan pengapian ini disebut ignition delay. Ignition delay adalah suatu parameter yang sangat berpengaruh terhadap awal sampai akhir proses pembakaran di dalam silinder bakar mesin, oleh sebab itu sangat menentukan performa dan emisi gas buang mesin. Pada pengujian di sini, sebagai mesin berbahan bakar ganda.Bahan Bakar Gas (BBG), yaitu; propana, metana, dan hidrogen masing-masing dialirkan ke dalam silinder bakar mesin diesel konvensional, setelah bercampur dengan udara oleh sebuah mixer yang ditempatkan di dalam intake port. Kemudian bahan bakar solar disemprotkan langsung ke dalam silinder mesin dengan jumlah kecil (hanya sebagai pemicu api saja), dan ignition delay solar yang diinjeksikan tersebut dengan periode injeksi yang bervariasi dianalisis dan dievaluasi. Pada penelitian ini telah dilakukan dan ditemukan model perhitungan untuk memprediksi ignition delay, yaitu dengan menerapkan persyaratan autoignition Livengood-Wu (Livengood dan Wu, 1955). Dengan didapatkannya model perhitungan untuk memprediksi ignition delay ini maka diharapkan dapat mempermudah dan meningkatkan akurasi hasil yang didapat di dalam penelitian pada level simulasi khususnya pada bidang mesin diesel.
\end{abstract}

Kata kunci: Keterlambatan pengapian, periode injeksi, periode pengapian, prediksi, bahan bakar ganda.

\begin{abstract}
In diesel engines there is the lag time between injection of diesel fuel since the beginning (injection period) into the cylinder combustion engine, then formed a mixture of air +moisture diesel until there is a point which first fire or ignition period. The grace period or ignition delay is called the ignition delay. Ignition delay is a parameter that greatly affects the beginning to the end of the process of fuel combustion in the engine cylinder and therefore determine the performance and engine exhaust emissions. In testing here, as a dual-fuel engines, fuel gas, namely propane, methane, and hydrogen respectively supplied to the cylinder combustion conventional diesel engines, after mixing with air by a mixer placed in the intake ports. Then the diesel fuel is sprayed directly into the cylinder machine with a small amount (just as the trigger fires only), and the ignition delay of diesel fuel is injected with variable injection period is analyzed and evaluated. In this study has been carried out and found the model calculations to predict the ignition delay, ie by applying the requirements of auto ignition Livengood-Wu (Livengood and Wu, 1955). With the acquisition of model calculations to predict the ignition delay is then expected to simplify and improve the accuracy of the results obtained in the study at the level of simulation, especially in the field of diesel engines.
\end{abstract}

Keywords: Ignitiondelay, injection period, ignition period, prediction, dual fuel.

\section{PENDAHULUAN}

Pada mesin diesel ada tenggang waktu antara sejak dimulainya penginjeksian solar (periode injeksi), kemudian meningkatnya tekanan dan temperatur sampai batas tertentu akibat gerakan menekan dari piston maka campuran udara + solar di dalam ruang bakar mesin mengalami terjadinya titik api yang mula-mula sehingga campuran terbakar. Tenggang waktu dari periode injeksi solar sampai terjadinya titik api yang mula-mula disebut ignition delay. Ignition delay adalah suatu parameter yang sangat mempengaruhi dari awal sampai akhir proses pembakaran di dalam silinder mesin diesel, oleh sebab itu sangat mempengaruhi performa dan emisi gas buang mesin, sehingga dari 
dahulu telah banyak penelitian [1-11] dilakukan. Dewasa ini, telah banyak riset terhadap mesin diesel berbahan bakar ganda, yang memungkinkan bahan bakar gas (BBG), seperti; Liquified Petroleum Gas, Compressed Natural Gas, dan lain-lain, dipakai sebagai bahan bakar utama [12-17]. Karena antara udara dan BBG dapat bercampur dengan baik, dan konsentrasinya dapat diatur dengan mudah, sehingga dengan memilih perioda injeksi solar yang tepat waktu, diharapkan NOx dan asap dapat ditekan sekaligus dalam waktu yang bersamaan. Mesin diesel diketahui mempunyai efisiensi panas yang tinggi dan fleksibel terhadap jenis bahan bakar. Oleh sebab itu mesin diesel banyak digunakan dalam berbagai keperluan.

Pada penelitian ini masing-masing BBG; propana, metana, dan hidrogen dialirkan bersamasama udara melalui intake port ke dalam silinder mesin sebagai bahan bakar utama, dan sebagai pemicu api bahan bakar solar disemprotkan langsung ke dalam silinder mesin dengan jumlah kecil. Ignition delay pembakaran di dalam silinder mesin yang diakibatkan injeksi solar tersebut dianalisis dan dievaluasi. Laju pelepasan panas (rate of heat release) dihitung dari penurunan tekanan dari hasil pengukuran langsung selama proses pembakaran, dengan menggunakan model oneregion dari Hukum I Thermodinamika. Keterkaitan antara karakteristik laju pelepasan panas dan karakteristik ignition delay juga dianalisis.

Kemudian model perhitungan untuk memprediksi ignition delay telah dapat dilakukan dan ditemukan pada bagian penelitian ini, yaitu dengan menerapkan persyaratan autoignition Livengood$\mathrm{Wu}$ [1]. Dengan didapatkannya model perhitungan untuk memprediksi ignition delay ini maka dapat mempermudah dan meningkatkan akurasi hasil yang didapat di dalam penelitian pada level simulasi khususnya pada bidang dunia mesin diesel.

\section{METODE PENELITIAN}

Pengujian ini dilakukan dengan menggunakan Mesin Diesel, 4-tak, silinder tunggal. Diameter (bore) dan langkah (stroke) masing-masing adalah 92 dan $96 \mathrm{~mm}$. Periode injeksi solar dapat dibuat dengan variasi yang sangat luas, dari mulai $21^{\circ}$ sebelum titik mati atas (before top dead centre, BTDC) sampai $5^{\circ}$ setelah titik mati atas (after top dead centre, ATDC). Rasio kompresi adalah 17,7, dan tipe silinder bakar adalah cekung dalam (deep dish) pada bagian atas piston. Spesifikasi mesin yang digunakan, ditunjukkan pada Tabel 1, dan skematik piston di dalam silinder bakar serta tipenya ditunjukkan pada Gambar 1. Kop silinder diperlengkapi dengan sensor tekanan untuk pengukuran tekanan pada proses pembakaran berlangsung, yang akan dipergunakan untuk perhitungan parameter-parameter yang dibutuhkan, misalnya; untuk menghitung laju pelepasan panas dan temperatur dalam silinder. Sinyal tekanan dalam silinder, sinyal TDC (Top Dead Centre), dan sinyal bukaan katup dideteksi oleh sebuah gap sensor yang ditampung pada sebuah perekam digital. Thermocouple digunakan untuk mengukur temperatur udara dan gas, dan flowmeter digunakan untuk mengukur debit udara dan gas, yang ditempatkan di dalam intake port.

Masing-masing BBG; propana (kemurnian 99\%), metana (kemurnian 99\%), dan hidrogen dialirkan ke dalam silinder bakar setelah melalui mixer udaragas. Kemudian, dengan jumlah yang sedikit, bahan bakar solar (cetane number 61) diinjeksi langsung ke dalam silinder bakar. Temperatur udara terdiri dari dua kondisi yang berbeda yaitu, 293 dan $307 \mathrm{~K}$. Temperatur air pendingin dan oli pelumas mesin masing-masing sama, yaitu $60{ }^{\circ} \mathrm{C}$.

Pada pengujian dengan kondisi memakai BBG atau dual-fuel, solar diinjeksikan hanya $4 \mathrm{mg} / \mathrm{cycle}$, atau rasio equivalensi setara dengan 0.08 , dan rasio equivalensi keseluruhan $\phi_{t}=0.25 \sim 0.52$, sedangkan pengujian tanpa BBG (solar 100\%, single-fuel) mesin mengkonsumsi solar berkisar antara 11.2 18.7 $\mathrm{mg} / \mathrm{cycle}\left(\phi_{t}=0.25 \sim 0.43, n=1000 \mathrm{rpm}\right)$.

Tabel 1. Spesifikasi Mesin

\begin{tabular}{lc}
\hline Tipe mesin & $\begin{array}{c}\text { Pendingin air, 4-tak, DI } \\
\text { Diesel Engine }\end{array}$ \\
\hline Ruang bakar & $\begin{array}{c}\text { Silinder-tunggal, cekung } \\
\text { dalam piston atas }\end{array}$ \\
Diameter (bore) $\times$ langkah (mm) & $92 \times 96$ \\
Isi silinder (cc) & 638 \\
Rasio kompresi & 17.7 \\
Diameter nozel injector (mm) & 0.26 \\
(jumlah lobang, sudut injeksi) & (4-lobang, 150 ) \\
Tekanan injeksi (MPa) & 19.6 \\
Perioda injeksi & Variable (sesuai \\
& kebutuhan yang sangat \\
Kecepatan putar mesin (rpm) & luas) \\
\hline
\end{tabular}

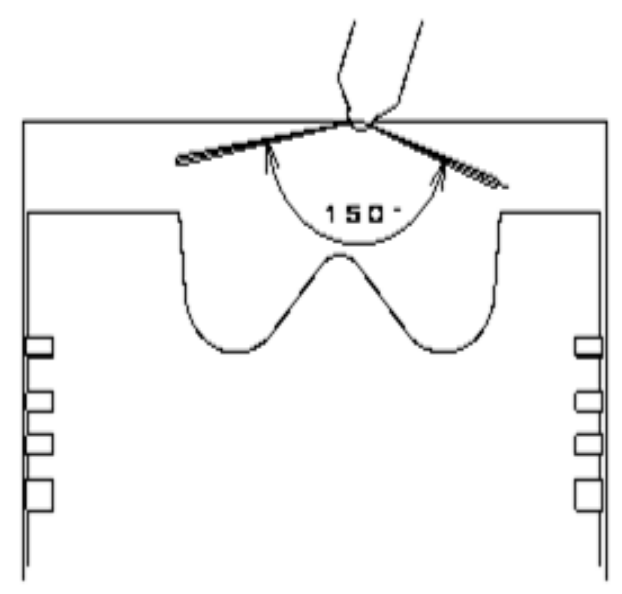

Gambar 1. Skematik Posisi Piston di dalam Silinder 
Tabel 2. Kondisi Pngujian

\begin{tabular}{ccccc}
\hline Kondisi & Perioda injeksi (deg. BTDC) & \multicolumn{2}{c}{ Kondisi lingkungan } & \multirow{2}{*}{ Rasio ekuivalensi total } \\
\cline { 3 - 4 } & & Gas masuk & Temp. $(\mathrm{K})$ & \\
\hline I A & $20 \sim 0$ & Udara & 291 & $0.31,0.42$ \\
I B & $21 \sim(-5)$ & Udara & 307 & $0.25,0.34,0.43$ \\
IIIP & $20 \sim 0$ & Udara $+\mathrm{C}_{3} \mathrm{H}_{8}$ & 293 & $0.29,0.37,0.47$ \\
IIIM & $20 \sim 0$ & Udara $+\mathrm{CH}_{4}$ & 293 & $0.29,0.37,0.47$ \\
IIIH & $21 \sim(-1)$ & Udara $+\mathrm{H}_{2}$ & 307 & $0.23,0.36,0.52$ \\
\hline
\end{tabular}

\section{Laju Pelepasan Panas}

Laju pelepasan panas dihitung dan dianalisis dari hasil penurunan tekanan dari pengukuran langsung selama proses pembakaran di dalam silinder dengan menggunakan model one-region dari hukum I Thermodinamika. Laju pelepasan panas $d Q / d \theta$ diperoleh dengan asumsi mengabaikan kehilangan panas dan gas di dalam silinder bakar tersebar merata. Dari Hukum Thermodinamika I $d Q=d U+P d V$ diperoleh;

$$
\begin{aligned}
\frac{d Q}{d \theta} & =\frac{d U}{d \theta}+P \frac{d V}{d \theta} \\
& =\frac{c_{V}}{R}\left(P \frac{d V}{d \theta}+V \frac{d P}{d \theta}\right)+P \frac{d V}{d \theta} \\
& =\frac{1}{\kappa-1}\left(P \frac{d V}{d \theta}+V \frac{d P}{d \theta}\right)+P \frac{d V}{d \theta} \\
& =\frac{\kappa}{\kappa-1} P \frac{d V}{d \theta}+\frac{\kappa}{\kappa-1} V \frac{d P}{d \theta}
\end{aligned}
$$

$Q$ : panas yang dilepas (J), $U$ : energi dalam (J), $P$ : tekanan di dalam silinder $(\mathrm{Pa}), c_{v}$ : spesifik panas volume tetap, $V$ : volume silinder $\left(\mathrm{m}^{3}\right), \kappa$ : rasio spesifik panas, dan $\theta$ : sudut putar mesin (deg.)

\section{Pengukuran Ignition Delay}

Ada berbagai cara mendefinisikan ignition delay, pada penelitian ini didasarkan dari analisis data laju pelepasan panas (rate of heat release), yang dihitung dari penurunan tekanan dari pengukuran langsung di dalam silinder bakar. Gambar 2 diperlihatkan contoh cara mendefenisikan ignition delay. Ignition delay $\Delta \theta$ [deg.] (tenggang waktu $\tau[\mathrm{ms}])$ di sini adalah waktu dari mulai periode injeksi solar $\theta_{i n j}$, hingga lintasan grafik laju pelepasan panas yang menanjak tajam $\left(\theta_{i g}\right)$.

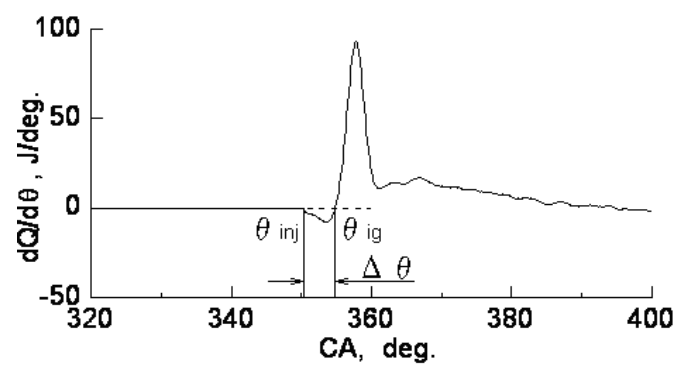

Gambar 2. Defenisi Ignition Delay

\section{Prediksi Ignition Delay}

Dari mulai penginjeksian solar (perioda injeksi) ke dalam silinder sampai terjadi titik api yang mulamula (autoignition), yaitu tenggang waktu selama ignition delay, tekanan (konsentrasi mol oksigen, $\left.\left[\mathrm{O}_{2}\right]\right)$ dan temperatur di dalam ruang bakar terus berubah. Di dalam hal supaya dicapainya autoignition yaitu terjadinya titik apiyang mula-mula ada persyaratan yang berlaku yang harus dipenuhi oleh konsentrasi mol oksigen $\left[\mathrm{O}_{2}\right]$ dan temperatur $T$ di dalam ruang bakar mesin. Dengan memanfaatkan persyaratan tersebut dapat dibuat prakiraan atau prediksi ignition delay $\Delta \theta$ [deg.] (atau $\tau[\mathrm{ms}]$ ) yang dapat menjadi model perhitungan untuk prediksi ignition delay solar yang perumusannya menggunakan persyaratan autoignition Livengood$\mathrm{Wu}$, yaitu persyaratan tercapainya titik api yang mula-mula pada campuran antara udara+ solar atau campuran udara + BBG + solar sebagai berikut:

$\int_{0}^{\tau} \frac{1}{\sigma} d t=1$

$\square \square \square$ adalah ignition delay yang oleh banyak peneliti telah menjadikannya referensi bahkan menawarkannya menjadi rumusan perhitungan hasil dari penelitiannya, yang pada pokoknya adalah fungsi dari temperatur $T$ dan tekanan (atau konsentrasi mol oksigen $\left[\mathrm{O}_{2}\right]$ ). Rumus tersebut adalah bentuk rumus Arrhenius, sebagai berikut:

$$
\sigma=\mathrm{A}\left[\mathrm{O}_{2}\right]^{\mathrm{B}} \exp \left(\frac{\mathrm{C}}{\mathrm{T}}\right)
$$

Di mana, $A, B$, dan $C$ adalah konstanta, $\left[\mathrm{O}_{2}\right]$ adalah konsentrasi $\mathrm{mol} \mathrm{O}_{2}\left(\mathrm{~mol} / \mathrm{m}^{3}\right)$. Selang waktu $\tau[\mathrm{ms}]$ adalah ignition delay yang menjadi hasil prediksi perolehan integral Persamaan 1 yang mana apabila integralnya mencapai jumlah 1 berarti campuran di dalam ruang bakar telah mencapai konsentrasi mol $\mathrm{O}_{2}$ dan temperatur yang cukup untuk terjadi titik api yang mula-mula. Dari percobaan dengan silinder bakar volume tetap [2] dan bahan bakar solar yang sama dengan penelitian ini, $B$ diperoleh dengan rumus sebagai berikut: $B=1.16 T_{m} \times 10^{-3}-2.45$

$B$ adalah besaran tanpa dimensi, $T_{m}$ adalah temperatur rata-rata dari temperatur periode injeksi, 
$T_{i n j}$ dan temperatur ignition $T_{i g}$, yaitu $T_{m}=\left(T_{i n j}+T_{i g}\right) / 2$, $C=4650 \mathrm{~K}$ diperoleh dari percobaan Wolfer [3].Aadalah konstanta yang berubah terhadap berubahnya jenis BBG, sebagai berikut:

Udara $\quad: \mathrm{A}=1.2 \times 10^{-7}\left[\mathrm{~m}^{3-\mathrm{B}} / \mathrm{kmol}^{\mathrm{B}}\right]$

Udara+propane : $\mathrm{A}=1.0 \times 10^{-7}\left[\mathrm{~m}^{3-\mathrm{B}} / \mathrm{kmol}^{\mathrm{B}}\right]$

Udara+metana : $\mathrm{A}=0.9 \times 10^{-7}\left[\mathrm{~m}^{3-\mathrm{B}} / \mathrm{kmol}^{\mathrm{B}}\right]$

Udara+hydrogen: $\mathrm{A}=1.3 \times 10^{-7}\left[\mathrm{~m}^{3-\mathrm{B}} / \mathrm{kmol}^{\mathrm{B}}\right]$

\section{HASIL DAN PEMBAHASAN}

Gambar 3 dan 4 memperlihatkan kondisi periode injeksi solar $\theta_{i n j}=$ TDC terhadap laju pelepasan panas campuran hanya udara (single-fuel) dan campuran udara+propane (dual-fuel). Fluktuasi ignition delay siklus demi siklus sebanyak 25 sampling data dan pembakaran seterusnya, campuran hanya udara terlihat sangat stabil, akan tetapi sebaliknya campuran udara+propana sangat tidak stabil. Hal ini dapat dijelaskan pada kondisi penginjeksian sekitar TDC dimana temperatur campuran tinggi, mengakibatkan gas propana mulai mengalami reaksi oksidasi, sehingga dimungkinkan ada campuran udara + propana yang dapat menyala sendiri (autoignition) mendahului solar, yang menghasilkan pembakaran berfluktuasi sangat dasyat.

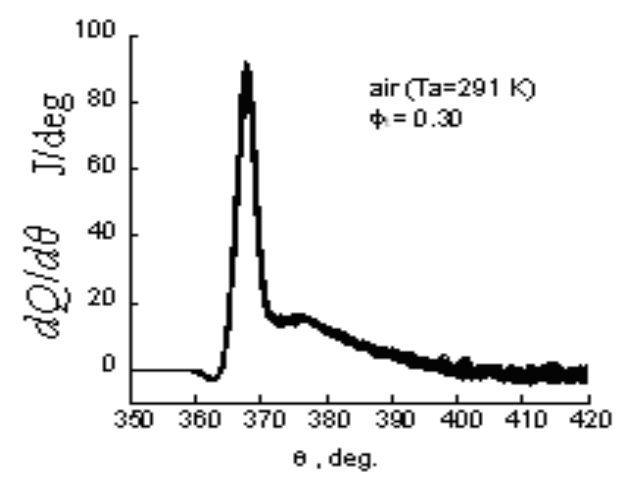

Gambar 3. Fluktuasi Laju Pelepasan Panas Siklus demi Siklus (injeksi TDC ke dalam campuran udara)

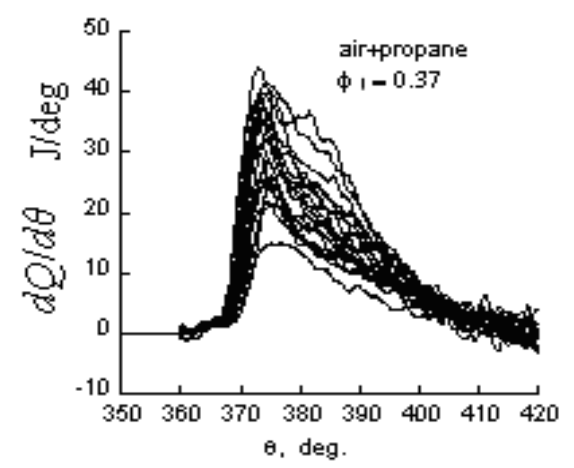

Gambar 4. Fluktuasi Laju Pelepasan Panas Siklus demi Siklus (injeksi TDC ke dalam campuran udara + propana)
Gambar 5 dan 6 adalah dua kondisi campuran udara+propana sebanyak 25 data sampling yang dibakar dengan autoignition injeksi solar, yaitu pada periode $\theta_{i n j}=$ TDC dan $19^{\circ}$ BTDC, yang memperlihatkan hasil integral Livengood-Wu ( $K$ adalah nilai pada bagian kiri dari Persamaan 1) dari mulai periode injeksi hingga terjadi titik api yang mulamula. Untuk hal ini, nilai $\tau$ diambil dari hasil percobaan. Kemudian, Gambar 7 dan 8 memperlihatkan frekwensi nilai $K$ hasil dari integrasi LivengoodWu pada periode autoignition (permulaan terjadinya titik api). Pada periode injeksi solar, $\theta_{i n j}=19^{\circ}$ BTD, fluktuasi periode autoignition relatif sangat kecil, lagi, nilai integral $K$ juga hampir mendekati nilai 1 . Akan tetapi, seperti kondisi pada $\theta_{i n j}=0^{\circ}$ BTDC, nilai hasil percobaan yang berfluktuasi sangat dahsyat, menyebabkan nilai $K$ yang berbeda-beda juga. Sehingga kemungkinan memprediksi dengan memakai Persamaan 1 kurang cocok. Untuk keadaan yang seperti ini, dimana untuk mendapatkan hasil prediksi yang optimum perlu dianalisis reaksi kimianya secara cermat.

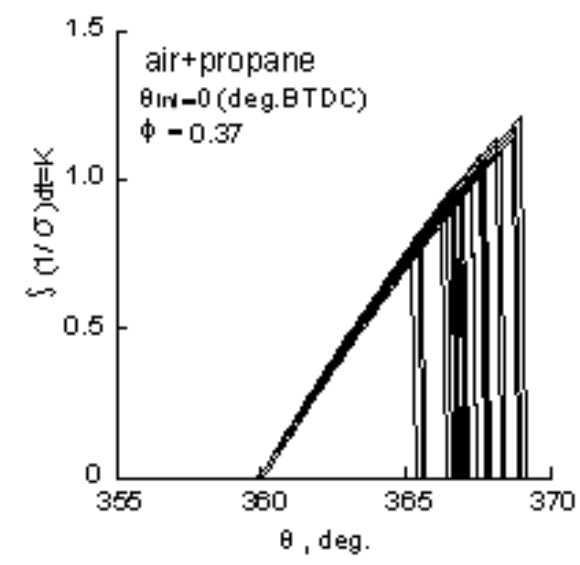

Gambar 5. Integral dari Livengood-Wu $\left(\theta_{i n j}=0\right.$ [deg.BTDC])

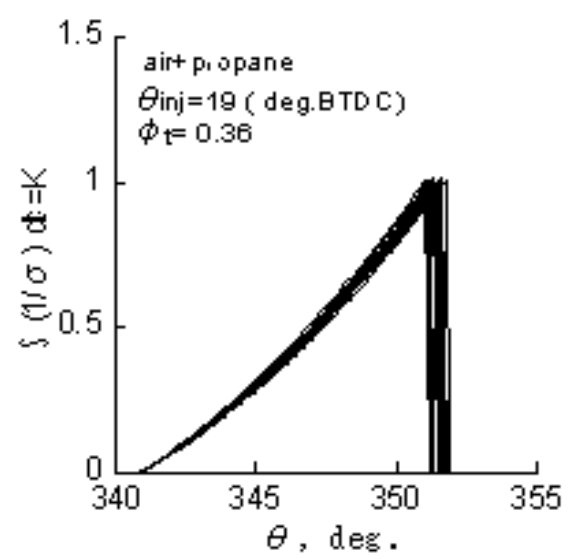

Gambar 6. Integral dari Livengood-Wu $\left(\theta_{i n j}=19\right.$ [deg.BTDC]) 


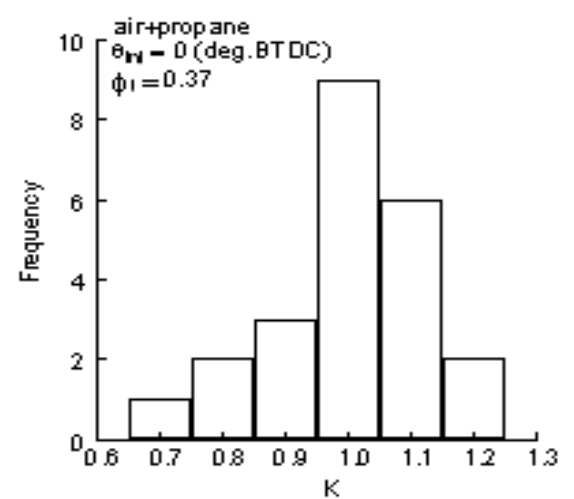

Gambar 7. Distribusi Integral Livengood-Wu $\left(\theta_{i n j}=0\right.$ [deg.BTDC])

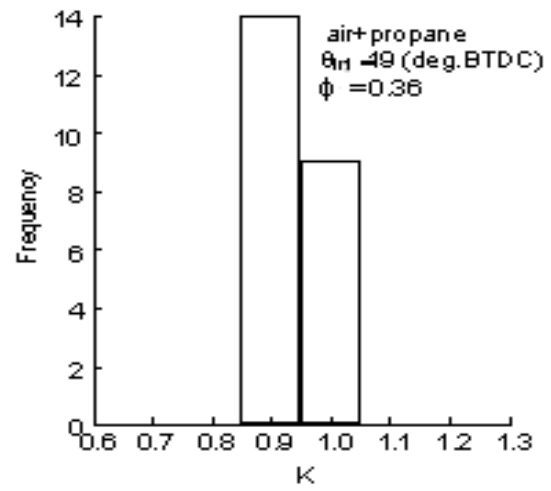

Gambar 8. Distribusi Integral Livengood-Wu $\left(\theta_{i n j}=19\right.$ [deg.BTDC])

Gambar 9, 10, 11, dan 12, masing-masing menunjukkan hubungan ignition delay $\tau$ dari hasil pengukuran dan dari hasil prediksi (perhitungan) dari periode injeksi solar hingga autoignition tercapai. Kecepatan mesin, $n=1000 \mathrm{rpm}$ (konstan), masing-masing kondisi campuran hanya udara, udara + propana, udara + metana, dan udara + hidrogen. Untuk semua kondisi yang berbeda-beda menghasilkan nilai prediksi yang hampir sama.

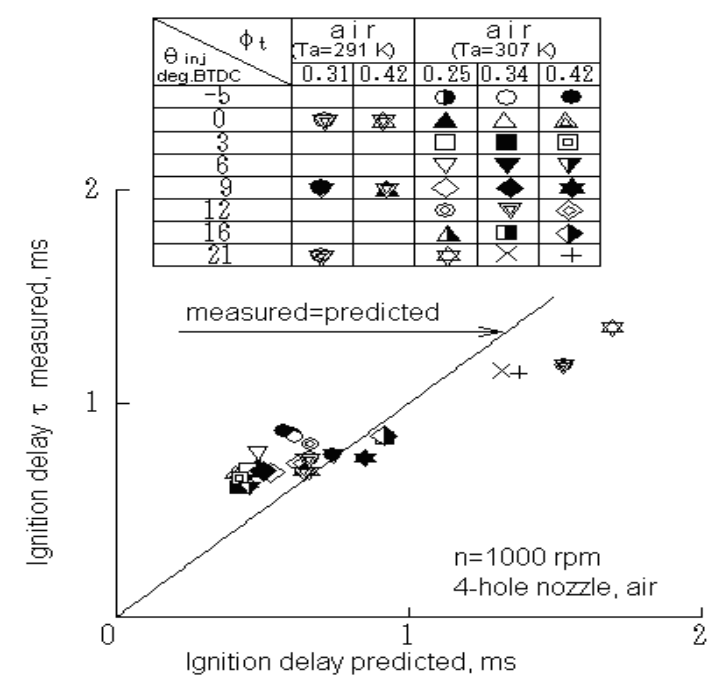

Gambar 9. Perbandingan antara Ignition Delay Pengukuran dan Prediksi (udara $T a=291$ dan $T a=307 \mathrm{~K}$ ) $\mathrm{n}=1000 \mathrm{rpm}$
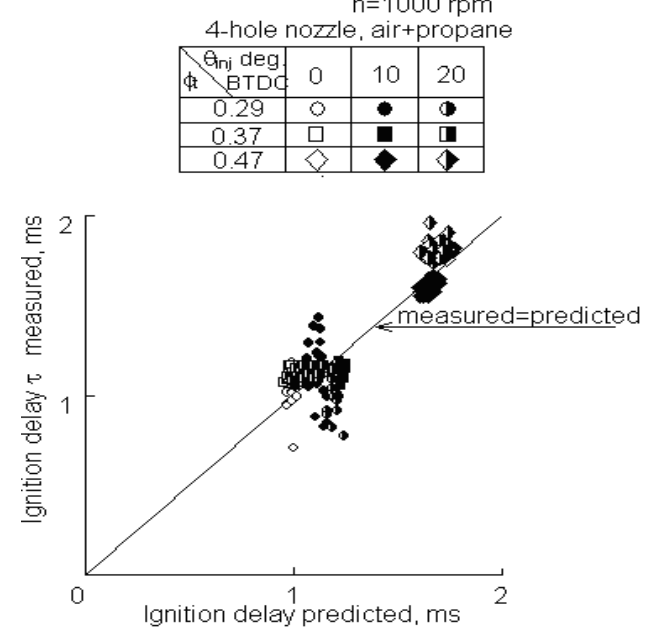

Gambar 10. Perbandingan antara Ignition Delay Pengukuran dan Prediksi (udara+propana)

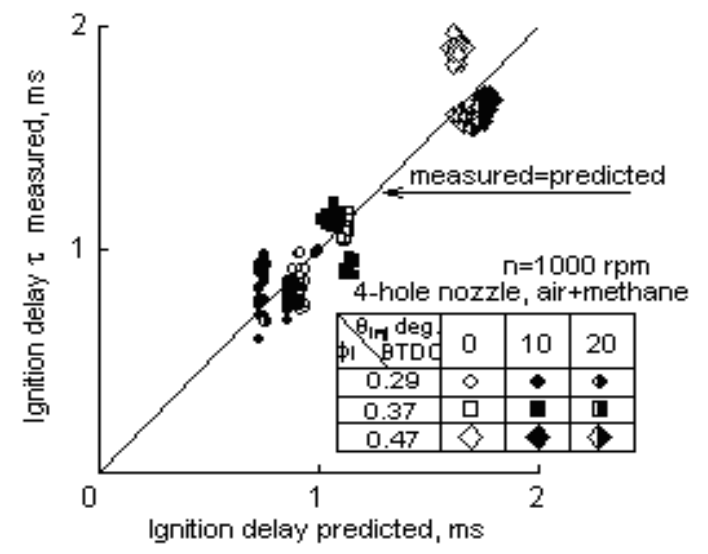

Gambar 11. Perbandingan antara Ignition Delay Pengukuran dan Prediksi (udara+metana)

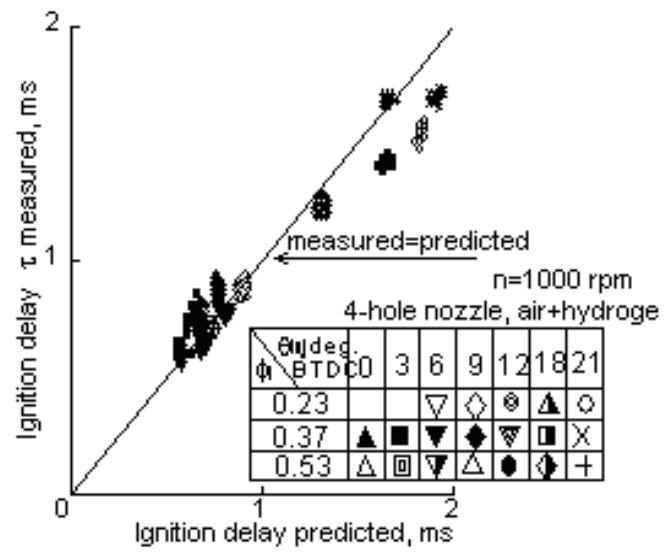

Gambar 12. Perbandingan antara Ignition Delay Pengukuran dan prediksi (udara+hidrogen)

Pada Gambar 13 ditunjukkan ignition delay hasil prediksi dan hasil pengukuran langsung, pada kondisi campuran hanya udara dan kecepatan mesin $n$, yang berbeda-beda. Pada kondisi yang seperti inipun, ignition delay dapat diprediksi dengan baik, dapat dilihat dari nilai prediksi hampir sama. 


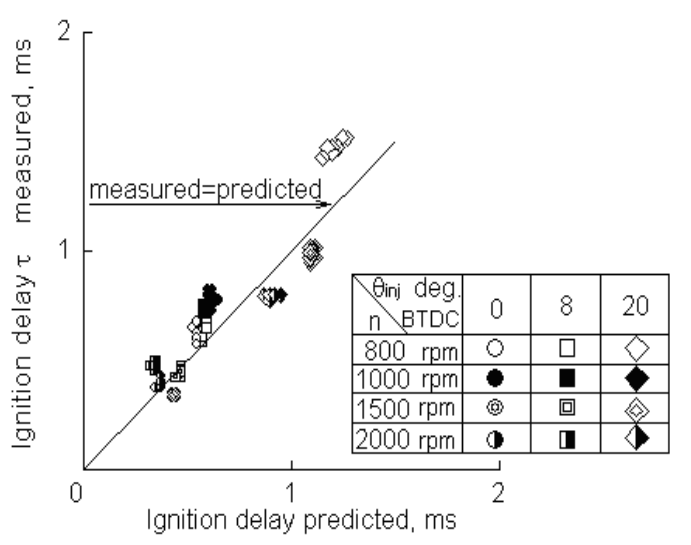

Gambar 13. Perbandingan antara Ignition Delay Pengukuran dan Prediksi (udara)

\section{KESIMPULAN}

Ignition delay mesin diesel konvensional dapat diprediksi dengan menerapkan model perhitungan syarat autoignition Livengood-Wu, baik untuk mesin diesel konvensional 100\% (single-fuel) maupun untuk mesin diesel berbahan bakar ganda (dualfuel). Di sini, untuk tetapan $C$ diperoleh dari referensi dari percobaan Wolfer, nilai tetapan $B$ diperoleh dengan referensi dari hasil percobaan dengan silinder bakar volume tetap. Jadi dengan hanya mengganti nilai $A$, sesuai dengan jenis BBG yang digunakan, diketahui bahwa ignition delay dapat diprediksi dengan akurat. Akan tetapi pada kondisi dual-fuel dan periode injeksi sekitar TDC, teristimewa untuk propana, karena temperaturnya lebih rendah akibat penurunan rasio spesifik panas dibandingkan dengan metana dan hidrogen, mengakibatkan proses pembakaranselanjutnyapun menunjukkan kecenderungan berfluktuasi. Namun demikian dalam kondisi seperti inipun ignition delay dapat diprediksi dengan relatif akurat.

Dengan didapatkannya model perhitungan untuk memprediksi ignition delay ini maka diharapkan dapat mempermudah dan meningkatkan akurasi hasil penelitian simulasi pada mesin diesel.

\section{DAFTAR PUSTAKA}

[1] Livengood, J.C. and Wu, P.C., Autoignition Phenomena in Combustion Engines and Rapid Compression Machines, $5^{\text {th }}$ Symp. (Int.), on Comb., 347-356, Reinhold Publishing Corp. (1955)

[2] Hamamoto, Tomita, Matsuoka, Hirata, Watanabe, Study on Ignition Assessment of Diesel Engine, JSA Paper, pp. 65-69, 25-2 (1994).

[3] Wolfer, H.H., Der Zundverzug im Dieselmotor, VDI-Forsch.,392, pp.15-24, (1938-9)

[4] Yu, T.C., Uyehara, O.A., Myers, P.S., Collins, R.N., Mahadevan, K., Physical and Chemical Ignition Delay in an Operating Diesel Engine
Using the Hot-Motored Engine, SAE Trans., Vol. 64, pp. 690-702, (1956).

[5] Tsao, K.C., Myers, P.S., Uyehara, O.A., Gas Temperature During Compression in Motored and Fired Diesel Engine, pp. 136-145, (1962).

[6] Lyn, W-T., Valdmanis, E., The Effects of Physical Factors on Ignition Delay, Proc Instn Mech Engrs, pp. 34-59, (1966-67).

[7] Henein, N.A. and Bolt, J.A., Ignition Delay in Diesel Engine, SAE Paper, No. 670007, (1967).

[8] Henein, N.A. and Bolt, J.A., Correlation of Air Charge Temperature and Ignition Delay for Saveral Fuels in a Diesel Engine, SAE Paper, No. 690252, (1969).

[9] Hamamoto, Oota, Ito, Study on Ignition Delay of Diesel Engine, JSA Paper, pp. 9-15, 9(1975)

[10] Ikura, Tsumida, Hiroyasu, Ignition Delay of Diesel Spray of Combustion Vessel Constant Volum, JSME Paper (B Edition), pp. 15591568, 41-345 (1975).

[11] Hiroyasu, Tsumida, Tanaka, Ignition Delay of Diesel Engine Spray Hit the Wall, JSME Paper (B Edition), pp. 531-539, 46-403 (1980).

[12] Arai, Mizoguchi, Hiroyasu, Ignition Delay of Light Oil and Saveral of Fuel, JSME Paper (B Edition), pp.1345-1353, 50-453 (1984).

[13] Ryan, T. W., Correlation of Physical and Chemical Ignition Delay to Cetane Number, SAE Paper, No. 852103, (1985).

[14] Dimitriu, D. G., Goetler, H.J., Ziejewski, M., Apparatus for the Measurement of Ignition Delay Times for Diesel Engine Fuels, SAE Paper, No. 901617 pp. 513-520, (1990).

[15] Liu Z., Karim G. A., The Ignition Delay Period in Dual Fuel Engines, SAE Paper, No.950466, (1995).

[16] Siebers, D.L. and Edwards, C.F., Autoignition of Methanol and Natural Gas in a Simulated Diesel Environment, SAE Paper, No. 910227, (1991).

[17] Daiso, Yasigeo, Kibara, Saitou, Kozeki, Shimi$\mathrm{zu}$, Characteristics of Combustion and Low Emissions of Dual-Fuel Engine (1 ${ }^{\text {st }}$ Journal of The Using Natural Gas to Ignited by Light Oil), JSA Paper, pp. 23-28, 27-3 (1996).

[18] Sato, Saito, Daiso, Combustion of Dual-Fuel Diesel Engine, JSA Paper, pp. 21-26, 26-3 (1995).

[19] Barata, J. M. M., Performance and Emissions of a Dual Fueled DI Diesel Engine, SAE Paper, No. 952364, (1995).

[20] Goto, Hida, Autoignition Compression and Autoignition Premixed Combustion Engine of DME and n-Butane Fuel, JSME Paper (B Edition), pp. 279-286, 64-618 (1998). 